\section{IJIKMMENA}

\section{1,2}

\title{
ENTREPRENEURSHIP TRAINING TO PROMOTE START-UPS AND INNOVATION IN BAHRAIN
}

\author{
Abdulhasan Al-Dairi' \\ Bahrain Polytechnic, Bahrain \\ Ronald McQuaid ${ }^{2}$ \\ Edinburgh Napier University, UK \\ John Adams ${ }^{3}$ \\ The British University in Egypt, Egypt
}

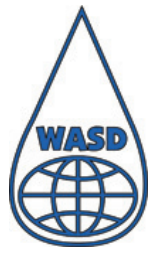

International Journal of Innovation and Knowledge Management in Middle East \& North Africa Vol. 1 No. 2, 2012

\begin{abstract}
${ }^{1}$ Dr Abdulhasan Al-Dairi, Bahrain Polytechnic, PO Box 33349, Isa Town, KINGDOM of BAHRAIN.

${ }^{2}$ Professor Ronald McQuaid, Director, Employment Research Institute, Edinburgh Napier University, Craiglockhart, Edinburgh, EH14 1DJ, UK, Email: r.mcquaid@napier.ac.uk. ${ }^{3}$ Professor John Adams, Head of Department of Economics, The British University in Egypt, Misr-Ismalia Road, CAIRO, EGYPT.

Abstract: Purpose: The purpose of this paper is to investigate training and education support for entrepreneurship in Bahrain, using the case study of the Entrepreneurship Development Programme (EDP).

Design/methodology/approach: The paper uses interviews, secondary sources and participant involvement on the part of one of the authors.

Findings: The United Nation Industrial Development Organization (UNIDO) and other initiatives to promote entrepreneurship in Bahrain are discussed. The characteristics of implementation of entrepreneurship training and education are set out, identifying the importance of 'hands on' practice and results orientation. 79 participants in the EDP were interviewed and their characteristics related to starting up a business discussed.

Research limitations/implications: The main limitations include the need for further evaluation of the initiatives discussed and measures of external business
\end{abstract}


environment. The sample size, the length of tracking of individuals and measures of external business environment are limited.

Originality/value: These results set out the wider polices to promote entrepreneurship in a small Gulf country and some of the factors that influence their likely success.

Keywords: Entrepreneurship; Start-up; Training; Entrepreneurship Development Programme; Bahrain.
Entrepreneurship training to promote start-ups and innovation in Bahrain

\section{INTRODUCTION}

Entrepreneurship is widely accepted as one of the most important determinants of economic development and job creation, as well as increasing innovation and other changes in society (Malechi, 1997; Baumol, 1993; Vyakarnam and Handelberg, 2005; OECD, 1998, 2010). Amajor policy issue throughout the Middle East and North Africa is how to increase the numbers and development of entrepreneurs, and in the Gulf region, there is a growing acceptance of the vital contribution entrepreneurs make in this respect (UN, 2004). Innovationis integral to entrepreneurship (Schumpeter, 1942) and can lead to both quantum leveland incremental changes in the provision of new goods/services (Bygrave, 1995, Bygrave and Hofer, 1991). There has long been a link between new and small firm size and increased innovationin terms of: newproducts or ways of production or procedures; new business models, organisational forms and institutions; and environmental sustainability, depending on the motivations of the firm and the presence of market failures that provide the opportunities for profitable development while reducing environmental degradation (Dean and McMullen, 2007; Schaltegger and Wagner, 2011). However,it is important to note that many new businesses are not innovative (Bhide, 2000). 
IJIKMMENA

\section{1,2}

181

In the context of the fluctuating price of oil and diminishing oil reserves, Bahrain has developed a strategy to diversify and stabilize its economy. There has been a focus on developing a knowledge-based economy (Al-Obaidy, 2012), and also on developing a competitive micro-, small- and medium-size enterprises (MSMEs) sector, delivering international quality products and services and contributing to quality employment opportunities.

More generally, the International Labour Organization (ILO, 1998) adopted the following recommendation (Recommendation 189 concerning general conditions to stimulate job creation and improve equality in Small and Medium-sized Enterprises):

"..... noting that small and medium-sized enterprises, as a critical factor in economic growth and development, are increasingly responsible for the creation of the majority of jobs throughout the world. They can help create an environment for innovation and entrepreneurship, understanding the special value of productive, sustainable and quality jobs, and recognizing that small and medium-sized enterprises provide the potential for women and other traditionally disadvantaged groups to gain access under better conditions to productive, sustainable and quality employment opportunities".

Although the term 'entrepreneurship' has various meanings (Ahmed and McQuaid, 2005), in this paper we primarily focus on entrepreneurship as the act of being an entrepreneur - "one who undertakes innovations, finance and business acumen in an effort to transform innovations into economic goods" (Shane, 2003). Educated entrepreneurs are more effective and efficient in planning, controlling and directing, thus securing sustainable development for their business (Roudaki, 2010). Entrepreneurship education is 
concerned with developing enterprising people, and learning in new ways, rather than starting up businesses or encouraging the systematic identification of opportunities (Drucker, 1985; Gibb, 2003; Packhamet al., 2010). In this paper we shall focus primarily upon this view of entrepreneurship as a form of behaviour entrepreneurship (especially as education changes thought processes and behaviour), but also particularly onentrepreneurship as starting a new business (Gartner, 1988).

Given the potential advantages of entrepreneurship, an important issue is how to encourage its positive growth. This paper investigatesinitiatives to improve innovative entrepreneurship education and training in Bahrain. The next section considers the literature on entrepreneurship training and MSMEs. This is followed by a discussion of UNIDO support for entrepreneurship training in Bahrain.The specific cases of training and further education in entrepreneurship, specifically the Entrepreneurship Development Programme (EDP), are then discussed. Finally, the conclusions are presented.

\section{ENTREPRENEURSHIP TRAININGAND MSMES}

There has been a long history of entrepreneurship education, particularly in the USA. Understanding how entrepreneurs develop, the circumstances that can foster or induce entrepreneurship, and the mind-set and beliefs of entrepreneurs could prove helpful both in supporting the existing body of entrepreneurs and in expanding the ranks of entrepreneurs (Wadhwaet al., 2009).

Entrepreneurial education has become increasingly important, partly due to globalisation leading to changes in the structure of economies (Hannon, 2007; Pittaway and Cope, 2007). There are two schools of thought on the issue of how
Entrepreneurship training to promote start-ups and innovation in Bahrain 
IJIKMMENA education or training may affect entrepreneurial spirit. Hagen 1,2 (1962), Fleming (1979) and Shapero and Sokol(1982) maintain that "entrepreneurs are born and not made" and that education or training plays a secondary role in promoting entrepreneurship spirit at its best. They claim that entrepreneurial characteristics such as creativity, risk bearing and determination are inherent qualities and may not be cultivated through education or training. Indeed, some go to the extent of saying that the entrepreneurial spirit of many individuals is dampened by the education system: entrepreneurs generally prefer an action-oriented approach, while traditional education systems may encourage an academic approach, which places greater emphasis on symbolic work (Kao, 1989). However,Nafukho and Muyia (2010) argue that the development of entrepreneurial competences and spirit should be a lifelong process.

McClelland (1965), however, argues that basic personal characteristics associated with entrepreneurship may be influenced by education as well as upbringing and other social factors. Gibb (1987) similarly reasons that since the entrepreneurial role appears to be culturally and experientially acquired, it might be influenced both by education and training.In addition, certain characteristics that may be influenced by education may only indirectly influence entrepreneurship. For instance, Heinonen et al. (2011) found that creativity was not associated with the viability of the business ideas of students, but it does strengthen the creativity of strategies to search for opportunities. While the debate concerning whether or not entrepreneurship can be taught often focuses upon motivations and inherent characteristics, education may in addition supply basic knowledge that is important in forming and running a business (e.g. marketing, financial and strategic understanding and knowledge). 
Various outcomes can be attributed to entrepreneurship education, one of which is whether students go on to start businesses at some time after the course. Although an immediate result (in terms of starting a business) may not occur, a variety of other outcomes associated with teaching entrepreneurship can be seen. For example, Blais (1997) gives at least seven reasons for making entrepreneurship a mandatory part of undergraduate engineering education. Blais' reasons include: to add a practical bias for both students and faculty; to provide a strong motivation for students to become more creative and innovative; to encourage and improve students' ability to work with others in team and joint venture initiatives; to act as a valuable initiation to the social sciences; to introduce students to small business concepts; to encourage engineers to start ventures and play an important role in job creation; to nurture regional development through start-ups; and to enhance skills and knowledge in relation to intrapreneurship in existing ventures. Entrepreneurship training also develops other transferable skills such as team working, leadership and communication skills together with general and specific business skills (e.g. marketing) (Jones and Jones, 2011).

Feedback about the venturing rate of students after they have taken one or more courses in entrepreneurship suggests that courses may improve the start-up rates of participants. Some eighty-seven per cent of graduates from the entrepreneurship programme at Swinburne University in Australia started their own business or becameintrapreneurs (McMullan and Gillin, 1998). Graduates with a degree in entrepreneurship were found to have a higher venturing rate than graduates from other disciplines (Kolvereid and Moen, 1997). Upton et al. (1995) found that several years after graduation, 40 per cent of entrepreneurship graduates had started their own firms, 30 per cent worked in a family business, and 30 per cent worked for a corporation. Charney and Lidecap (2000)
Entrepreneurship training to promote start-ups and innovation in Bahrain 184 
IJIKMMENA in the USA report that just over a quarter of entrepreneur1,2 ship graduates (27 per cent) owned a business, compared with 9 per cent for graduates from other areas of business. Finally, results from a longitudinal study of engineering graduates in Canada show that venturing rates are considerably higher for those who had taken one course in entrepreneurship during their undergraduate programme. Only 26 per cent of a stratified, random sample comparison group had been a business owner at any time since graduation, compared with 48 per cent for the group that had taken one course in entrepreneurship (Menzies andParadi, 2002), although they later found no significant differences between the characteristics of these two groups (Menzies and Paradi, 2003). So overall, entrepreneurship education and training appears to be associated with higher business start-up rates.

\section{UNITED NATION INDUSTRIAL DEVELOPMENT ORGANIZATION (UNIDO) INITIATIVESIN BAHRAIN}

Although relatively few large firms are of crucial importance in the Bahrain economy in terms of their contributions to GDP and employment, micro enterprises still represent around 87.7 per cent (41,033 establishments) of the total MSME sector. Small enterprises make up around 10 per cent (4,760 establishments), while the medium enterprises constitute the final 1.7 per cent (808 establishments). Micro, small and medium enterprises represent a significant part of the Bahraini economy contributing, according to Central Informatics Organization estimates, nearly 28 per cent of total nominal GDP, particularly in construction, manufacturing and trading, which are the three main industries within this sector (Bahrain Annual Economic Review, 2010). Micro, small and medium enterprises also provided jobs for nearly 73 per cent of private sector employees, only 14 per cent of which are Bahraini employees, however, and 86 per cent are 
non-Bahrainis. Broken down by gender, 90 per cent of these employees are male, and only 10 per cent are female.

The UNIDO Investment \& Technology Promotion Office (ITPO) of Bahrain, in cooperation with the Ministry of Industry (MoI) and various entities in Bahrain concerned with development of SMEs, have been attempting to stimulate domestic as well as foreign investment into the country in order to boost the manufacturing sector. It was concluded that the limited availability of qualified entrepreneurs as well as a cohesive set of support services posed major bottlenecks in Bahrain. As a result, an Enterprise Development process was initiated, giving due consideration to the operational environment in Bahrain and the special needs of the Bahraini entrepreneurs. The process called for resources and organisational co-operation, i.e., the availability of trained people to act as trainers and counsellors, helping and guiding potential entrepreneurs; and networking with concerned institutions involved in facilitating small enterprise development. These were seen as being essential for long-term sustainability and the institutionalization of the process. Two case studies are now described which illustrate training-and education-based support for entrepreneurs: the Arab Regional Centre for Entrepreneurship and Investment Training; and the Bahrain Training Institute further education courses for potential entrepreneurs.

\section{ESTABLISHMENT OF THE ARAB REGIONAL CENTRE FOR ENTREPRENEURSHIP AND INVESTMENT TRAINING (ARCEIT) IN BAHRAIN}

Bahrain was identified as the Regional Focal Point Country for the Arab Region by the IRC, jointly sponsored by UNIDO and the Government of India with the objective of strengthening the indigenous capacities of selected countries in Arab,
Entrepreneurship training to promote start-ups and innovation in Bahrain 186 
IJIKMMENA Asian and African regions in the areas of investment promo1,2 tion and entrepreneurship development. The cooperation and support extended by the government and the local institutions and the response from the community in the GCC region led to the establishment of the "Arab Regional Centre for Entrepreneurship and Investment Training (ARCEIT)" in Bahrain, to effectively organize and support the Investment and Technology Promotion and Entrepreneurship Development Initiatives in the Arab region - the core elements of the Enterprise Training programme (ETP, sometimes called the Enterprise Development programme, but called the ETP here to avoid confusion with the Bahrain Training Institute's Enterprise Development programme).

ARCEIT operates with the objective of developing and strengthening the indigenous capabilities of developing countries in the Arab region for Investment and Technology Promotion (ITP) and Entrepreneurship Development. The activities of the ARCEIT are closely coordinated by the UNIDO Investment and the Technology Promotion Office in Bahrain and UNIDO HQ in order to ensure maximum synergy among the institutional participants.

ARCEIT networked with the Bahraini Ministry of Industry, which has a mandate to promote and facilitate industrial development, and the Bahrain Development Bank, whose mandate includes meeting the financial needs of SMEs in Bahrain, facilitating enterprise creation through training and counselling intervention. Through this association a unique model of services has been offered to budding small entrepreneurs in Bahrain. It offers the following package in sequential order: 


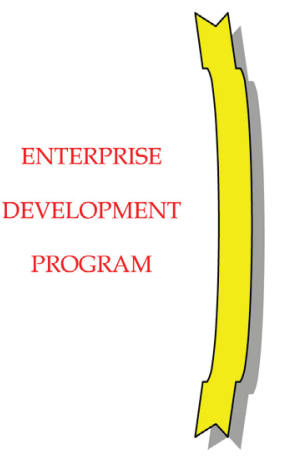

Capacity Building Service/Training

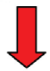

Counselling \& Technology Tie-up possibly

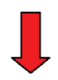

Leading to a full-fledged Joint Venture

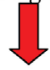

Financial Services
Entrepreneurship

training to promote start-ups and innovation in

Bahrain

188

Figure I:

Enterprise

Development

Programme

This support package, pioneered and institutionalized in Bahrain, has now been implemented in other countries in the region through local Institutions. Bahrain was established as a focal point for Entrepreneurship Development training for the promotion of small enterprise development in the region. The Entrepreneurship Training Programme is run by the Arab Regional Centre for Entrepreneurship and Investment Training (ARCEIT), which is part of UNIDO's Office in Bahrain.

\section{I st STEP - Capacity Building Services}

The Entrepreneurship Development process is based on a theory that entrepreneurs are not only born but can also be trained and developed. It is, of course, recognized that all individuals do not possess entrepreneurial traits or the desire to start one's own business, but some do have such traits, irrespective of the socio-economic class to which they belong. It is expected that people can be trained to become fullyfledged entrepreneurs through training (such as the Entrepreneurship Development and Enterprise Creation Programme) which strengthens their 
IJIKMMENA confidence in their own ability to start a new business, im1,2 parts necessary skills and knowledge about financial, technical and managerial aspects of business and provides information for identifying a project idea.

The basic characteristics of EDP as it has evolved are as follows:

a) The training process is result-oriented in the sense that the potential entrepreneur is expected to set up his own business enterprise- appropriate to his abilities and background after the training and as a result of the training;

b) There is a firm commitment to its basic objectives by the organizing institutions;

c) The trainees are identified and selected through a systematically evolved selection process involving personality and commitment assessment through written tests and personal interviews. This means that there is some homogeneity in the group undergoing the learning process in a supportive environment.

Based on the above philosophy, the programme aimed to help potential entrepreneurs translate their ideas into commercial ventures in manufacturing/service sectors.

\section{The Programme Content}

With the ultimate objective of assisting potential entrepreneurs to set up their own enterprises, the programme is designed to cover the following:

- Setting up a small enterprise in Bahrain: rules, procedures and formalities, whom to contact for what, 
the nature and extent of assistance available from various institutions;

- Business opportunity identification: how to identify Business Opportunities, and how to screen them in order to firm up a Business Idea for further exploration;

- Market assessment: how to assess the market potential, guidance in carrying out field work for market assessment for the proposed product/service;

- Entrepreneurial competencies: behavioural science-based inputs to strengthen 'soft' skills/entrepreneurial competencies;

- Business Plan skills: skills in preparing a Business Plan and assistance in finalising one;

- Essentials of managing an enterprise;

- Inputs on how to implement a project.

Input weights were determined on the basis of a profile of the participant group selected for the respective programme. The training lasts for a period of 4-5 weeks.

\section{2nd STEP - Counselling \& Technology Tie-ups:}

Subsequent to the classroom training, there is a vigorous follow-up mechanism to provide business counselling with the ultimate objective of facilitating project implementation (business start-up). Trained entrepreneurs are helped in finalizing their business ideas and in obtaining the necessary information and guidance to prepare their business plans. A crucial stepenables entrepreneursto source technology tie-ups,
Entrepreneurship training to promote start-ups and innovation in Bahrain 
IJIKMMENA which could also allow for the development of a full-fledged 1,2 partnership. This setup is carried out through the UNIDOITPO/IPU Network (see below). In addition, ITPO Bahrain is linked with public institutions in the Kingdom such as the Ministry of Industry and the Ministry of Commerce in order to facilitate further support and assistance.

Administrative support on legal and licensing issues is facilitated through the Ministry of Commerce, where an agreement has been made in order to provide a Commercial Registration (CR) and other related support to entrepreneurs on condition that they have graduated and have been counselled by the ARCEIT. This also applies to the Ministry of Industry for permits and exemptions as well as acquiring land in Industrial Estates if needed.

It may be noted that the nature and extent of business counselling services depends on the needs of the individual entrepreneurs. The Counselling and Technology Tie-up step is a lengthy relationship between the counsellor and the entrepreneur. It may generally include the following activities:

- Business opportunity identification, analysis and finalisation;

- Market research - collection, analysis and compilation of relevant data;

- Identification and sourcing information on appropriate technology, machinery/equipment, and raw materials etc.;

- Facilitating technology tie ups and joint venture collaborations (see below); 
- Business plan preparation;

- Completing legal documentation and seeking necessary registrations, licenses and clearances;

- Finalising project implementation plan.
Entrepreneurship training to promote start-ups and innovation in

Bahrain

\section{3rd STEP - Financial Services}

The third step of the service links the business counselling to facilitation of the finances of the scheme. Appropriate financial linkage is based on the project requirements and the entrepreneur's investment capacity.

Entrepreneurs are advised and guided on completing the required formalities for seeking loan support from the financial institution. At this stage, needs-based advice and support is also provided by the financial counsellors. The business counsellor acts as a link between the entrepreneur, the financial counsellor and the financial institution in order to facilitate the process and ensure the project's linkage with the financial scheme.

\section{4th STEP - Business Development Services and Advisory for Enterprise Growth, Including Establishment of Business Incubators and Technology Park}

With all the essential resources for the project agreed, the entrepreneur is guided through the project implementation plan, formulated during the counselling phase (Step 2). Essential linkages are facilitated with institutions dealing in services related to the entrepreneur's needs. Considerable capacity building is provided throughout the programme 
IJIKMMENA in terms of technical, marketing access and linkages; con1,2 tinuous follow-up with institutions delivering administrative services, such as the Ministry of Commerce, Ministry of Industry and others. Day-to-day follow-up with entrepreneurs on different issues is provided to support and sustain their smooth growth. Needs-based guidance and support are extended for procurement, installation and commissioning of the project machinery and equipment as well as for procuring the raw materials and other utilities. A business advisor, in association with the financial counsellor, closely monitors the project implementation process and guides the project to operational fruition.

Suitable projects requiring basic infrastructural services offered by the business incubator are selected and facilitated to operate from the incubator. This provides them with subsidized essential infrastructure and administrative services together with business advisory services, in order to overcome initial teething problems. Tailor-made business advisory as well as training interventions are brought in to ensure project survival at crucial stages of initial operation and to facilitate growth in the subsequent period of project operation.

Ten intakes were successfully conducted between 2001 and 2004. The programme has trained 159 potential entrepreneurs, which has lead to the establishment of 65 businesses. The programme has also provided counselling and growth interventions to 200 entrepreneurs, which cover support to existing and new enterprises. Three intakes were conducted each year in which 47 entrepreneurs were trained and provided with the necessary support to facilitate the smooth implementation and development of their businesses. 
Through the UNIDO ITPO/ IPU Network ${ }^{1}$ of offices (Brazil, Belgium, China, France, Greece, Italy, Japan, Poland, Korea, Russian Federation, United Kingdom, Jordan, Morocco, Tunisia and Egypt) ITPO Bahrain provides a wide spectrum of services offered to Entrepreneurs during the Counselling and Technology Tie-up step.
Entrepreneurship training to promote start-ups and innovation in Bahrain

\section{ENTREPRENEURSHIP TRAININGIN BAHRAIN - THE ENTREPRENEURSHIP DEVELOPMENT PROGRAMME CASE STUDY}

A second strand of entrepreneurship promotion policy has been the development of further education courses for potential entrepreneurs. The weakness of the conformity between the output of the education system and the needs of the local market in Bahrain has been attributed to a number of factors, including administrative and professional decisions about expenditure, capacity and syllabus and course content and training (UNDP 1998; Farganiand Metwally, 2009). Oukil (2012) argues that education systems in the Middle East and North Africa are less practical and business oriented than those in leading developed and emerging countries and most education systems in the GCC have not kept up with the students' need for appropriate skills to effectively enter the labour market (Fargani and Metwally,2009; Harry, 2007).

${ }^{1}$ ITPOs/IPUs are one-stop shops for four services crucial to investment promotion and technology transfer: (i) dissemination of investment information, (ii) identification and promotion of investment opportunities, (iii) provision of training in promotional techniques and (iv) matching project sponsors with potential foreign investors. ITPO staff maintains active links with the business community and development agencies in the Offices' host countries as well as extensive data banks of companies interested in industrial partnerships in developing and transition economies. 
IJIKMMENA

\section{1,2}

195
The Bahrain Training Institute (BTI) was first established in 1978 as the Vocational Training Centre before changing its name to the current name in 1992 following core changes in the mechanism of its work and the programmes offered. It offers a wide range of vocational and technical education programmes ranging from Craft Certificate, First Diploma, National Diploma and HND, all at post-secondary level. Out of the total number of students admitted, 19 per cent were from Commercial Education. The BTI's records indicated that over 75 per cent of their graduates find employment within three to four months (BTI, 2000). This case study considers the period of the early 2000s when the entrepreneurship initiatives were being developed and embedded.

There were two main streams at BTI: Business and Technical training. The entrepreneurship development programmes provide knowledge and enabling skills to start business in either of these two streams. The BTI's overall vision is to develop Bahraini human resource through the pursuit of excellence in training. BTI attempts to promote in the trainees ethical standards, work culture and technical skills to support the development of a robust, equitable and sustainable Bahraini economy. The aims of the component to support entrepreneurship - the Entrepreneurship Development Programme (EDP)- were as follows:

- To introduce trainees to the entrepreneurial spirit and encourage them to consider self-earning activities after they graduate;

- To provide training in the skills required to succeed in entrepreneurial pursuits and expose trainees to the realities of business, including the work ethic;

- To inculcate common skills so that they can become productive as soon as they start working; 
- To integrate the technical and entrepreneurial training components by requiring all trainees to study the theory and practice of entrepreneurialism along with their major specializations;

- To identify special areas suitable for female trainees within their culture context: IT, business studies and garment technology;

- To provide exposure to the real workplace and to develop an appreciation of the nature of the business through the on-job training component;

- To provide work class training by using internationally developed training standards;

- To provide technical and vocational skills in appropriate areas.

\section{FEATURES OF ENTREPRENEURIAL TRAINING AT BTI}

The objectives of the entrepreneurship training were two-fold. On the one hand, this training aimed to introduce trainees to the entrepreneurial spirit and provide skills to undertake self-earning activities after they graduate. On the other hand, the training systematically exposed trainees to the work ethic and business realities so that they could succeed in future employment. The integration of vocational and entrepreneurial development training took place at four levels, as follows:

a) At the foundation level, along with the other technical courses, trainees studied a course called the world of work. Trainees are encouraged to develop an understanding of the environment in which they live and the work opportunities it provides. In addition to the knowledge they were given about
Entrepreneurship training to promote start-ups and innovation in

Bahrain 
IJIKMMENA the work environment, trainees received a simple introduc1,2 tion to the work ethic necessary to succeed. They were systematically trained in maintaining good personal hygiene, to have the appropriate dress sense and to appreciate the importance of punctuality and other good work habits, including teamwork and loyalty to the workplace. They were given basic training in good communication skills and awareness of health and safety principles. Finally, they were encouraged to take the first steps in planning their careers by becoming aware of their aspirations and strengths.

b) At the first diploma level, trainees were required to study the course entitled vocational preparation. In this course, they were given practice in developing skills such as identifying work opportunities and understanding job descriptions. They were introduced to the essential communication skills necessary in applying for jobs and operating in a workplace. The overall aim was to encourage trainees to systematically identify work opportunities and then to prepare themselves to use them. They were also encouraged to examine their own potential and to move into independent work after the initial work experience.

c) At the National Diploma Year 1 level, trainees investigated the relationship between industry and society. They developed awareness of the economic and financial structures that regulate the economy and their role in generating wealth. The opportunity was taken to inform the trainees about the process of human resource selection and appointment in the industry and attention was drawn to the role of HR development in an industrial setting.

d) In Year 2 (the final year of the National Diploma), the trainees studied Entrepreneurship. The aim of this course was to inculcate in the trainees a positive attitude to self-earning 
activities, clarify their relationship to national economic activities and provide an introduction to the skills necessary to succeed in an entrepreneurial project.

\section{CHARACTERISTICS OF THE EDP COURSE}

Bahrain's human resources policies give special attention to the needs of women. Economic and demographic pressures require that more women contribute to the economy by joining the workforce. In relation to training, BTI selected the following areas suitable for the involvement of women: information technology, garment technology and business management. A number of female trainees embarked upon entrepreneurial activities in areas such as information technology and the garment sector.

An important characteristic of the course was the inclusion of on-job training to provide exposure to the entrepreneurial aspect of business. The chief aim of the on-job training component of a vocational and entrepreneurship training programme was to provide trainees with exposure to the real world of work and experience of working in it. The EDP's programme added another facet by requiring trainees to understand and appreciate the business aspect of a business organisation, including administration, purchasing, marketing and sales along with the technical operations. The important innovation was that apart from getting exposure to the real workplace and the opportunity to absorb the appropriate work ethic, on-job training also provided trainees with an insight into the entrepreneurial aspect of a business.

Most young people who are keen on starting their own businesses lack funds. They can have good and practical ideas and may possess the willingness to work hard. However, lack of funding makes it difficult to translate their ideas into practice.
Entrepreneurship training to promote start-ups and innovation in Bahrain 
IJIKMMENA In Bahrain, an effort is being made to develop incubation 1,2 centres where budding entrepreneurs are helped to develop their ideas into practical projects, including support to obtain funding. These centres also provide consultancy throughout the initial phases of the project. As discussed above, trainees in the final year of their training were required to develop business plans and present them formally. The best of these plans were then selected for submission to funding agencies, including the Bahrain Development Bank.

Bahrain is a participant in the Micro start programme of the UNDP, which suggests measures to support the development of the private sector. This programme provides a number of services including training and workshops as well as backup support to new and existing training institutions, access to best practice, and advice on mobilizing resources. The EDP included features of the Micro start programme to strengthen the development of the private sector in the country.

Since the development of the private sector and encouragement for self-earning activities has been the policy of the Bahraini Government for some time, a number of related initiatives have been taken by various government ministries and institutions. BTI's entrepreneurship development programme has built systematic links with such initiatives and made a conscious effort to become part of the entrepreneurship development network in the country.

BTI established mechanisms to encourage the contribution of business practitioners and other professionals to its curriculums. Every department had a Programme Development Committee, which includes prominent practitioners in that particular field of training. The involvement of practitioners in developing curriculums and monitoring training activity ensured that BTI training retained its practical orientation. In 
addition to getting information about the knowledge and the skills levels required in the real world of work, inputs of practitioners highlighted the importance of learning the correct work ethic for trainees. BTI trainees were made aware that employers expect them to be productive as soon as they start working and that working in a team and arriving at work on time is often as important as the ability to perform technical functions. Trainees also get the benefit of listening directly to leaders in industry and business, who were invited to address them. These sessions enabled trainees to develop an insight into the entrepreneurial spirit behind business organizations.

Apart from the integration of technical and entrepreneurship training, BTI attempted to develop a unique approach to the delivery of programmes in entrepreneurship development. The programme aimed to replicate the process of launching an entrepreneurial activity and systematically guides the trainees through each of the stages. Courses in entrepreneurship development aimed to: motivate the trainee to make a self-appraisal in order to identify the traits he or she possesses that are necessary in becoming a successful entrepreneur; provide trainees with the knowledge and skills necessary to operate a successful business (including the ability to manage finances, adopt good accounting procedures, use a systematic approach to identify human resource needs and meeting these needs through reliable hiring practices, handle registration and licensing procedures, effective marketing and other crucial aspects of managing a business); identify business opportunities. They were encouraged to understand the concept of creativity in the light of business opportunities and its relationship with technological innovation; conduct feasibility studies; enable trainees to understand the process of starting a business; produce detailed business plans that articulate the critical aspects, basic assumption and financial projections regarding a business venture. The best plans were then forwarded to
Entrepreneurship training to promote start-ups and innovation in Bahrain 
IJIKMMENA the Bahrain Development Bank for consideration. The pro1,2 cess of writing a business plan was an invaluable experience for the trainees because it forced them to think through their business concept in a systematic way and replicated what they wouldbe required to do in the real world of business.

\section{1}

\section{Impacts Entrepreneurship Training Programme (EDP)}

Some 79 participants of the EDP were interviewed after they had completed the course over the period 2000 to 2006. They were asked about a range of issues including whether they had started up a business and the other impacts of the course on their working lives (Table 1).

\begin{tabular}{l|c|c|c|c}
\hline & Yes & Percent & No & Percent \\
\hline $\begin{array}{l}\text { Have you started your own } \\
\text { business? }\end{array}$ & 35 & 44 & 44 & 56 \\
\hline $\begin{array}{l}\text { Are you still in the same } \\
\text { business? }\end{array}$ & 16 & 20 & 63 & 80 \\
\hline $\begin{array}{l}\text { Do you want to start in fu- } \\
\text { ture? }\end{array}$ & 56 & 71 & 23 & 29 \\
\hline $\begin{array}{l}\text { Do you think you can per- } \\
\text { form your job/business in a } \\
\text { better way after joining the } \\
\text { Entrepreneurship Develop- } \\
\text { ment Programme (EDP)? }\end{array}$ & 45 & 57 & 30 & 38 \\
\hline $\begin{array}{l}\text { Did you start your own } \\
\text { business prior to (before) } \\
\text { joining this training pro- } \\
\text { gramme? }\end{array}$ & 22 & 28 & 57 & 72 \\
\hline \begin{tabular}{l}
$\mathbf{N}=\mathbf{7 9}$ \\
\hline
\end{tabular}
\end{tabular}

Table I:

Participant responses to the EDP 
Although the length of time since graduation varied, 56 per cent had not started their own business while 44 per cent (35) had started their own business. Moreover, a considerable percentage (28 per cent) mentioned that they had already started a business before the course, but in half the cases they were not in their original business, so the course may have been used to assist some of these to re-orientate their businesses. That could perhaps mean that they joined the programme to advance and enhance their business. For some, it was too early to start up, as in total, 71 per cent thought that they would eventually start a business.

The hypothesis that training is of benefit to potential entrepreneurs, even if they remained as employees, is somewhat supported as 57 per cent of them thought that they could perform their jobs/business in a better way after the training programme.

\section{CONCLUSIONS}

The United Nation Industrial Development Organization (UNIDO) and other initiatives to promote entrepreneurship in Bahrain were considered together with the characteristics of implementation of entrepreneurship training and education, including the intention to support greater female entrepreneurship. These were based upon the idea that entrepreneurship, or at least many key aspects, can be taught. Of importance is the need for 'hands on' practical components to the courses and a results orientation.

A small survey indicated that the courses had: increased the desire to start-up businesses among participants; been used by some participants who had already started up to reorientate or change their businesses; and in addition participants felt that the course had improved their performance as
Entrepreneurship training to promote start-ups and innovation in Bahrain 
IJIKMMENA employees. There is, however, a lack of in-depth analysis of 1,2 the impacts of entrepreneurship training and education in the region.

The importance of improving training and education to encourage entrepreneurship, including business start-up, is widely recognised in the Gulf region and this paper has described some initiatives in this area. However, continued support for entrepreneurship training and education is likely to be needed and greater research on the effects of different models of support is required.

\section{BIOGRAPHY}

Dr AbdulhasanAldairi is the president of Bahrain SMEs Society, a founding member and shareholder of various companies in and out of Bahrain. He has been a researcher and practitioner in the field of entrepreneurship and SMEs development for almost two decades. In 1995, he started teaching entrepreneurship to university students, which later became a full-fledged 'Entrepreneurship Training Department'. While serving as the Director of Community Centres at the Ministry of Social Development (2006-2010), he helped families to start their own enterprises through the 'Productive Family Program'. Currently, he is assisting Bahrain Polytechnic to launch its 'Enterprise Development Centre' during 2012.

Professor Ronald McQuaid is the Director of the Employment Research Institute at Edinburgh Napier University. He has carried out work for many regional, national and supra-national bodies such as the European Commission, various Governments, agencies and employers, and published in the fields of employment, innovation, entrepreneurship and economic development. 
Professor John Adams is Head of Department of Economics at the British University in Egypt. He has published widely in national and international academic journals, is co-author of five textbooks and also undertakes consultancy assignments for a wide range of public and private sector organisations in the UK and overseas. He is currently Visiting Professor at three universities in China, mainly focused on economic development. He is also an Executive Board member of the International Institute for Investment Promotion based in Zurich and holds editorships of four academic journals.

\section{REFERENCES}

Ahmed, A. and McQuaid, R.W. (2005), "Entrepreneurship, management, and sustainable development", World Review of Entrepreneurship, Management and Sustainable Development, Vol. 1 No. 1, pp.6-30.

Al-Obaidy, H.S. (2012), "Development alternative: building capacity for a knowledge-based economy in Bahrain", International Journal of Innovation and Knowledge

Management in Middle East and North Africa, Vol. 1 No. 1, pp. 57-79.

Baumol, W.J. (1993), "Formal entrepreneurship theory in economics: existence and bounds", Journal of Business Venturing, Vol. 3, pp.197-210.

Bhide, A. (2000), The Origin and Evolution of New Businesses Oxford University Press, Oxford.

Blais, R. A. (1997), Technological Entrepreneurship and Engineering in Canada, Canadian Academy of Engineering, Ottawa.
Entrepreneurship training to promote start-ups and innovation in Bahrain 
IJIKMMENA Bygrave, W.D. (1995), "Mom-and-pops, high potential

\section{1,2} startups and intrapreneurship: Are they part of the same entrepreneurship paradigm?” In J.A. Katz \& R.H. Brokhaus (Eds), Advances in entrepreneurship firm emergence and growth, JAI Press Greenwich,CT, pp.1-20.

Bygrave, W.D. and Hofe, C.W. (1991), "Theorizing about Entrepreneurship", Entrepreneurship Theory and Practice, Vol. 16 No. 2, pp. 13-22.

Charney, A. and Lidecap, G. D. (2000), The impact of entrepreneurship education: An evaluation of the Berger entrepreneurship program at the University of Arizona, 1985-99. Ewing Marion Kauffman Foundation, Tucson.

Dean, T.J. and McMullen, J.S. (2007), “Toward a Theory of Sustainable Entrepreneurship: Reducing Environmental Degradation through Entrepreneurial Action”. Journal of Business Venturing, Vol. 22 No. 1, pp. 50-76.

Drucker, P.F. (1985), Innovation and Entrepreneurship, Heinemann, London.

Eckhardt. J.T. and Shane, S.A. (2003), "Opportunities and Entrepreneurship”, Journal of Management, 2003, Vol. 29 No. 3, pp. 333-349.

Fargani, M. and Metwally, M. (2009), "Price elasticity of demand for Libya and the terms of trade of GCC countries", International Journal of Applied Business and Economic Research, Vol. 7 No. 2, pp.145-156.

Fleming, W.J. (1979), “The Cultural Determinants of Entrepreneurship and Economic Development: A Case Study of Mendoza Province”, Argentina, 1861-1914, 
Journal of Economic History, Vol. 39, pp. 211-224.

Gartner, W.B. (1988), "Who is an Entrepreneur? is the wrong question", Entrepreneurship Theory and Practice, Vol. 12, pp.47-67.

Gibb, A.A. (1987), "Education for Enterprise: Training for Small Business Initiation - Some Contrasts", Journal of Small Business and Entrepreneurship, Vol. 4 No.3, pp. $42-47$.

Gibb, A.A. (1993), "The enterprise culture and education: understanding enterprise education and its links with small business, entrepreneurship and wider educational goals", International Small Business Journal, Vol. 11 No. 3, pp. 11-34.

Gibb, A.A. (2003), "Organizing for enterprise in China: what can we learn from the Chinese micro, small, and medium enterprise development experience", Futures, Vol. 35 No. 4, pp. 403-421.

Hagen, E.E. (1962), On the theory of social change: how economic growth begins, Homewood, Dorsey Press.

Hannon, P. (2007),"Enterprise for all? The fragility of enterprise provision across England's HEIs", Journal of Small Business and Enterprise Development, Vol. 14 No. 2, pp.183 - 210 .

Harry, W. (2007),"Employment creation and localization: the crucial human resource issues for the GCC", The International Journal of Human Resource Management, Vol. 18 No. 1, pp. 132-146.

Heinonen, J., Hytti, U. and Stenholm, P. (2011), “The role
Entrepreneurship training to promote start-ups and innovation in Bahrain 
IJIKMMENA

\section{1,2}

of creativity in opportunity search and business idea creation", Education + Training, Vol. 53 No. 8/9, pp. 659-672.
ILO (1998), "Job Creation in Small and MediumSized Enterprises Recommendation, 1998 (R189)”,

Jones, A. and Jones, P. (2011), "Making an impact: a profile of a business planning competition in a university", Education + Training, Vol. 53 No. 8/9, pp. 704-721.

Kao, J.J. (ed.) (1989). Entrepreneurship Creativity and Organization. Prentice-Hall, Englewood Cliffs, NJ.

Kolvereid, L. and Moen, Ø. (1997),“Entrepreneurship among business graduates: does a major in entrepreneurship make a difference?" Journal of European Industrial Training, Vol. 21 No. 4, pp. 154-160.

Malechi, E.J. (1997), Technology and Economic Development: The Dynamics of Local, Regional and National Competitiveness, 2nd ed. Addison Wesley Longman Limited, London.

McClelland, D.C. (1965), "n-Achievement and entrepreneurship: A longitudinal study”, Journal of Personality and Social Psychology, Vol. 1 No. 4, pp. 389-392.

McMullan, W.E. and Gillin, L.M. (1998), "Industrial viewpoint: entrepreneurship education: developing technological start-up entrepreneurs: a case study of a graduate entrepreneurship programme at Swinburne University", Technovation, Vol. 18 No. 4, pp. 275-286. 
Menzies, T.V. and Paradi, J.C. (2002), "Encouraging technology-based ventures: Entrepreneurship education and engineering graduates", New England Journal of Entrepreneurship, Vol. 5 No. 2, pp. 57-64.

Menzies, T.V. and Paradi, J.C. (2003), "Entrepreneurship education and engineering students: Career path and business performance", International Journal of Entrepreneurship and Innovation, Vol. 6 No. 2, pp. 85-96.

Minniti, M. and Bygrave, W. (2001), "A Dynamic Model of Entrepreneurial Learning”, Journal Entrepreneurship: Theory and Practice, Vol. 25No. 3, pp. 5-16.

Myint, Y.M., Vyakarnam, S. and New, M.J. (2005),“The effect of social capital in new venture creation: the Cambridge high-technology cluster", Strategic Change, Vol. 14, pp.165-177.

Nafukho, F.N. and Muyia, M.A.H. (2010),"Entrepreneurship and socioeconomic development in Africa: a reality or myth?" Journal of European Industrial Training, Vol. 34 No. 2, pp.96-109.

Packham, G., Jones, P., Miller, C., Pickernell, D. and Thomas, B. (2010), "Attitudes towards entrepreneurship education: a comparative analysis", Education + Training, Vol. 52 Nos 8/9, pp. 568-86.

OECD (1998),"Fostering Entrepreneurship: A Thematic Review" Organisation for Economic Co-operation and Development OECD, Paris.

OECD (2010) SMEs, Entrepreneurship and Innovation Organisation for Economic
Entrepreneurship training to promote start-ups and innovation in Bahrain 
IJIKMMENA

1,2

209

Co-operation and Development, OECD, Paris. http://www.oecd.org/document/16/0,3746, en_2649_33956792_44938128_1_1_1_1,00.html

Oukil, M-S. (2012), "The Strategic importance of quality education in MENA countries towards innovation-driven economies and entrepreneurial societies", International Journal of Innovation and Knowledge Management in Middle East and North Africa, Vol. 1 No. 1, pp. 7-30.

Pittaway, L. and Cope, J. (2007), "Entrepreneurship education: a systematic review of the evidence", International Small Business Journal, Vol. 25 No. 5, pp. 477-506.

Roudaki, J. (2010), "Entrepreneurial Higher Education", Advances in Management, Vol 3 No. 8, Available at http:// managein.net/bk_issue/edit_3_8.htm

Schaltegger, S. and Wagner, M. (2011), "Sustainable entrepreneurship and sustainability innovation: categories and interactions", Business Strategy and the Environment, Vol. 20 No. 4, pp. 222-37.

Shane, S.A. (2003), A General Theory Of Entrepreneurship: The Individual-opportunity Nexus, Edward Elgar Publishing, Cheltenham, UK.

Shapero, A. and Sokol, L. (1982), "The Social Dimensions of Entrepreneurship”, in C. Kent, D. Sexton, and K. H. Vesper (eds.) The Encyclopaedia of Entrepreneurship, Englewood Cliffs, NJ: Prentice-Hall. pp. 72-90.

Schumpeter, J.A. (1942), Capitalism, socialism, and democracy, Harper,New York. 
UN (2004), "Unleashing Entrepreneurship: Making Business Work for the Poor", Report of the Commission of the Private Sector and Development to the UN, Available at: http://www.undp.org/cpsd/report/index.html.

Upton, N.B., Sexton, D.L. and Moore, C. (1995), "Have we made a difference? An examination of career activity of entrepreneurship majors since 1981", In Frontiers of Entrepreneurship Research1995 Edition, pp. 727-728.

Vyakarnam, S. and Handelberg, J. (2005), "Four Themes of the Impact of Management Teams on Organizational Performance Implications for Future Research of Entrepreneurial Teams”, International Small Business Journal, Vol. 23 No. 3, pp. 236-256.

Wadhwa, V., Saxenian, A.L., Freeman, R. B. and Gereffi, G. (2009), "America's Loss is the World's Gain: America's New Immigrant Entrepreneurs", Part 4, Working Paper Series, March 2.
Entrepreneurship training to promote start-ups and innovation in

Bahrain 